\title{
The significance of the religious factor in the internal and external policies of Turkey
}

The article aims to establish the reasons and manifestations of the increased importance of the religious factor in the policy of contemporary Turkey, as well as to capture the essence of transformations taking place in Turkish religious policy (Michalak, 2019a: 2335). The last process strictly corresponds to the phenomena of withdrawal from the model of non-religious autocracy which was one of the main characteristics of Kemalism in favour of the model of a country which is de facto religious. This, in turn, becomes the emblem of the shaping Erdoganism. The indicated goal is pursued basing on the method of critical analysis of the content of studies and available sources.

The Republic of Turkey, ruled in the 1920s and 1930s by Mustafa Kemal Atatürk, was the first state in the $20^{\text {th }}$ century to follow the model of secular autocracy. Religion, which determined the strength of the Ottoman identity and was the nucleus of Turkish pan-Islamism, was quickly eliminated from public space. In 1924, the caliphate was dissolved and the function of Mufti was introduced. The consequence of this decision was the closure of religious schools, de-Islamization of the universal educational model, marginalization of the ulema, and the dissolution of religious brotherhoods and monasteries. Furthermore, secularization resulted in the replacement of the Arabic alphabet with the Latin script, the introduction of the Gregorian calendar in place of the Muslim lunar timekeeping, the prohibition of wearing religious headgear, equalization of both genders in the light of the law and the granting of the right to inheritance and divorce for women, as well as many other anti-religious solutions. In 1928, the statement about Islam as a state religion was removed from the constitution (Lewis, 1972: 471-480). In 1931, secularism was listed among the six ideological and programme principles of the Republican People's Party (the so-called six arrows of Kemalism), alongside republicanism, nationalism, populism, statism and revolutionary reformism (Szymański, 2008: 58-71).

The radical secular nature of the state persisted until the 1950s, when monoparty rule remained in the hands of the politicians of the Kemalist Republican People's Party

\footnotetext{
* Correspondence address: Instytut Nauk o Polityce i Administracji, Uniwersytet Zielonogórski, Wojska Polskiego 69, 65-762 Zielona Góra, Polska, e-mail: r.michalak@ip.uz.zgora.pl.
} 
(Chmielowska, Sobczak, 2016: 205-232). Contrary to popular belief, Kemalism was hostile not only to Islam. By definition, secular autocracy had a negative attitude towards religion as such. When it comes to image, anti-Sunniism was dictated not so much by the critical assessment of those in power against the Sunni religious doctrine, but by the fact of its dominant role in the society. The principle of full separation of religious associations from the state, established by Atatürk, consequently gave rise to a religious policy oriented towards a liquidation course in relation to conservative - because those were dominant - trends of Sunniism, deeply restrictive towards Reform Sunniism, Sufism, Alawitism, Judaism and Christianity (Orthodoxy, Catholicism, Oriental trends - Armenian and Assyrian), and licensed against Kemalism - as de facto a substitute of religion.

In the 1950s and subsequent decades, during which the Kemalists power shared with other parties and Turkey began its course towards democracy, religious policy was dependent on a hostile separation model, much more radical than in the French variant (Zenderowski, Michalak, 2018). The constitution of 1982 confirmed the secular nature of the state and secularism as one of its main values (Dahl, 2017:33). Limiting directly liquidation actions, at the same time a direction of deep rationing was maintained by refusing religious associations any presence in the public sphere. The guarantor of separation was the army "anointed by Atatürk to act as a guardian of Turkish secularism" (Szkudlarek, 2014: 54) and - nolens volens - to the role of the final instance of the republic's religious policy. The army made several attempts to overthrow the existing order when there was a real risk of forming a government by pro-Islamic groups (Sulkowski, 2016a: 134; Zasuń, 2018: 481).

The change towards a hybrid state - combining the features of democracy and autocracy - which at the same time cultivates the bond with one religion (Islamic Sunniism) in an unfair way, marginalizing or discriminating against others, began in Turkey at the turn of the 1980s and 1990s with the rule of the Prime Minister (then President) Halil Turgut Özal. However, the changes in Turkish politics at the time were not of a systemic and doctrinal nature. This kind of process began for good in 2002, when the AKP, the Justice and Development Party, came to power (Urbanik, 2014: 32). It was then that European decision-makers began to question the sense of Turkey's admission to the European Union (Szymański, 2011: 91-94; Adamczyk, 2013). This scepticism was closely correlated with the AKP slogans about the need to restore Islam to its proper position in the Turkish state (Sulkowski, 2016b). After decades of interruption, day by day, Sunniism became, alongside Neoosmanism, the most important creation of the instrumentally created and basic identity of the Turks. References to Islamic law became increasingly obvious (Sadowski, 2017). The religious policyof the Republic of Turkey was focused on increased subjectivity and support - both financial and legal - of Sunni organizations (Falski, 2011: 122-147; Szkudlarek, 2014: 51-69; Brzdąkiewicz, 2018: 112140). The sublime thread accompanying this support is the differentiation of those or- 
ganizations and their rewarding depending on the place of these entities in the informal ranking. The order of this list is determined by the level of Sunni orthodoxy. Thus, the greater Sunni conservatism a given organization represents, the greater its chances of subsidising. Naturally, this conservatism must be closely correlated with pro-Erdoganism, or with the unambiguous and resounding support of Recep Tayyip Erdogan, the Prime Minister in 2003-2014, and from 2014 the President of Turkey. In the past, the activities of the AKP displayed involvement in religious organizations around the efforts of Mehmet Denizolgun for leadership in the Süleymancı community, as well as Kemalettin Özdemir for power in the Gülen movement. Today, the apparatus of power managed by Erdoğan plays out matters related to the organization's activity very skilfully: Ismailağa Cemaati, Naqshbandiyya, or Ismailağa Vakfı. Religious leaders who are disobedient towards Erdoğan are sentenced to jail, prison or banishment. This also applies to Sunni radicals, for instance Fetullah Gülen (living in exile in the USA) and Alparslan Kuytul (imprisoned for two years in Turkey). The elimination of religious leaders and the neutralization of Islamic organizations is not a major problem for the authorities, since in parallel to these activities, further associations are established or reactivated with new leaders for example TÜGVA (the Service for Youth and Education Foundation of Turkey) and TÜRGEV (Turkish Foundation to Serve the Youth and Education). On the board of the first organization sits daughter of President Esra Albayrak, and on the board of the latter is Bilal Erdoğan, son of Recep Tayyip (Çevik, 2019).

The actions of the Turkish President against 2 million Syrian refugees fit into the context of building a Sunniism that is powerful and subordinate to Sundog. In the future, this community may have a significant impact on the functioning of the Turkish state as long as Syrians obtain Turkish citizenship and, thus, acquire electoral rights. As noted by Karol Wasilewski,

For the ruling camp, which would probably be the beneficiary of the naturalization of Syrian refugees, this could prove to be a very valuable resource. It appears that the current electoral map could change the distribution of naturalized Syrians in a favourable way for the AKP, especially in Kurdish constituencies where the ruling party usually loses to HDP (People's Democratic Party). The implementation of such a scenario would probably strengthen the significance of Islam as a foundation of the new Turkey, and would weaken the role of nationalism. The ruling camp would have to emphasize the common elements of identity in order to gain support for the decision on naturalization and easier assimilation of the Sunni Syrian population (Wasilewski, 2017: 29).

The above scenario does not seem unlikely, even at a high risk of increasing tensions in the country, as the concept of granting citizenship to Syrians meets with strong opposition from Turkish society. The settlement of Syrian refugees on the territory of southeastern Turkey would also bring a conflict between Arabs and Kurds, inevitably leading to the ethnic decomposition of the region. However, this situation would suit Erdoğan due to the fact that he consistently perceives the Kurdish population to be the greatest 
threat to the integrity of the state, which he has confirmed by directing Turkish troops to Kurdish lands in northern Syria in October 2019.

An element of the religious policy of the concession of Sunni support by the AKP government is also constituted by a propaganda based on parascience, whereby it has an international dimension. This is how we should assess the value of annual reports on the so-called Islamophobia, which constitutes a product ordered by SETA, a pro-regime think tank from Ankara (European Islamophobia Report 2015, 2016; European Islamophobia Report 2016, 2017; European Islamophobia Report 2017, 2018; Ślusarczyk, 2017; Atakuja nas najemniczki Erdogana, 2018), whose motto can be reduced to the sentence: "Any criticism of Islam or Islamism equals Islamophobia". In this way, also Islamosceptic scientific reflection (Michalak, 2019b: 201-213) and expert analyses are subject to stigmatisation. A separate issue worth investigating are sources of uncritical reception of this type of views on the foundation of creativity concerning the far-left (credited with university affiliation). In this perspective, Islamophobia is replaced by an even higher level of accusations, e.g. those of racism (Ramme, 2019). Meanwhile, islamophobia located in the countries of Christian culture gives Erdoğan - a graduate of the Sunni school İmam Hatip Lisesi in Istanbul - an excuse to deepen the control policy towards Christian denominations. Already in 2011, during a meeting at the headquarters of the Patriarch of Constantinople in Istanbul, the World Council of Churches declared that in Turkey religious freedom and related rights are being increasingly violated by both the authorities and individuals. In 2011, the fact of rationing in relation to the few nonIslamic religious schools, for which the limitation was, among others, the obligation to employ a Muslim as a deputy director, was also noted (Zieliński, 2011:33). On this occasion, it is worth mentioning that courses such as The Life of the Prophet and Qur'an have been included in the programme of general (non-religious) schools (Çevik, 2019).

In subsequent years, the restrictions on non-Muslims increased. The President of Turkey even risked a conflict with the United States following the halting of the military coup in July 2016, when Andrew Brunson, a Presbyterian pastor of a small congregation in Izmir, who was related to coups for more than 20 years, found himself in Turkish custody in July 2016. The allegations made against the pastor were completely incoherent and without evidence: he was to be a member of the Fethullah Gülen movement, which was hostile to the AKP, cooperate with the forbidden Kurdistan Workers Party, be involved in espionage for the United States and plan a coup. Brunson's lawyer claimed that the actual reason for the arrest was "his client's Christian faith" (Gall, 2018). He was sentenced to three years and one and a half months in prison. The pastor was released in October 2018 after the Trump administration imposed economic sanctions on Turkey. Brunson returned to the United States. However, the case continued, as it created a pretext for the invigilation and rationing of the activities of Protestant and Mormon communities throughout Turkey. It also served to intensify anti-Americanism 
(and more often anti-oxydentalism and anti-liberalism) among Turkish society (Wódka, 2013: 23, 39, 46; Iddon, 2019) and to strengthen the myth of the New Turkey - born of effective repulsion of the putsch (Chudziak, 2017), for whom Eurasia would be the best environment for international cooperation.

Other actions of Erdoğan, which are to ensure him the reputation of an uncompromising defender of Sunni, include the defence of President Muhammad Mursi deposed in Egypt in 2013, along with his backing, i.e. the radical Muslim Brotherhood. In this context, it is difficult to deny their reasons to researchers of pan-Turkism and pan-communism who formulate the opinion that Turkey is leading not only a pro-Sunni, but above all a "sectarian foreign policy" (Wasilewski, 2017: 44). Regardless of this type of assessment, Turkish politicians take every opportunity to conduct 'mosque diplomacy' and emphasize their great care for the interests of Muslims around the world. As noted by the journalist of "Gazeta Wyborcza”, today Ankara "builds and renews Sunni mosques from Japan through Somalia, and even pays salaries to the Balkan imams" (Rostkowska, 2015). The beginning of 2019 saw the construction of thirty mosques on five continents. Investments are de facto directed by the ministry: Diyanet İşleri Başkanlığı, the Directorate of Religious Affairs (Ali Erbaş is the head of the institution since 2017), whereby the budget of the ministry increased in 2019 by $36 \%$ ( 1.7 billion euros, comprising $1.2 \%$ of the total budget), while the budget of the ministry of science, industry and technology has been reduced by $56 \%$.

It is currently five times larger than the expenses of the Ministry of Interior and six times those of the Turkish parliament. The Turkish religious office also finances the education of imams from other countries. In 2017, there were 2,140 students from 110 countries who studied in Turkey. Diyanet has eighteen schools with over 3,500 students worldwide - in Central Asia, the Balkans, Bangladesh, Malaysia, Somalia, but also in Haiti (Wójcik, 2019).

Other statistics emphasize that Diyanet owns 61 branches in 36 countries including Lithuania, Russia and Belarus.

Furthermore, it has been publishing and distributing the Quran and other religious books in 28 languages and financially supporting official Islamic representative institutions in the Balkans, Continental Europe and Africa. It has also been supplying educational and material support for imams in foreign countries and organizing official gatherings, such as Eurasia Islamic Council, Balkan Countries Islamic Council, Latin America Countries' Muslim Summit and African Religious Leaders Summit (Öztürk, 2018).

The maxim pronounced by Erdoğan for many years: "The mosques are our barracks, the domes our helmets, the minarets our bayonets and the faithful our soldiers" (Bekdil, 2015) has been taken on literally. On the other hand, the AKP politicians react with real hysteria to the actions of European countries that close Turkish mosques. This was the case in Austria in 2018. The decision of Chancellor Sebastian Kurz was described by the President of Turkey as "a step drawing the world into a new war between the Cru- 
saders and the Crescent" (Baran, 2018). The dispute between Kurzem and Erdoğan was part of a series of other events, including Austrian opposition to the acceptance of Turkey to the European Union (Husar-Poliszuk, Secler, Ślusarczyk, 2018: 40-43).

Created by the former Foreign Minister (2009-2014) and Head of the Turkish government (2014-2016), Ahmet Davutoğlu, the Turkish doctrine of domination in the Muslim world (Dahl, 2017: 34) is hence entering an even more dynamic phase, which Ömer Turan called the shift from "pan-Islamist populism" towards "Islamic nationalism" (Turan, 2018: 50). It should be emphasized that despite the clearly pro-Sunni selfdetermination of Turkey by its decision-makers, they want to avoid international conflicts (especially in the Middle East), in which there would be an "Islamic civil war", i.e. a conflict between the Sunni and Shia (Wódka, 2012; Jomma, 2018). In this context, Davutoğlu's statement from April 2012 may be referenced: "In the Middle East there are forces that want to emphasise religious divisions, but a possible religious conflict would be a suicide for the region" (Kopyś, 2013: 210). Jan Wójcik also emphasizes that since 2016, Erdoğan has also been active in other directions: "Turkey was often mixed up in German domestic politics, antagonizing the Turkish diaspora with the country of residence, there were more and more mentions of controlling mosques in Germany by Diyanet [...], the activity of the Turkish MIT intelligence was revealed" (Wójcik, 2018). The presumption of Turkish espionage also applies to Austria, the Netherlands, Switzerland and Denmark, and therefore to countries where there are diplomatic missions employing "religious diplomats" (Wójcik, 2019). Formulated twenty years ago, Samuel Huntington's forecast of neo-Ottoman Turkey as a leading candidate for leadership in the Islamic Civilisation (Huntington, 2000) is, therefore, beginning to find confirmation in the facts constituted by the decision-makers of that country, and with a surplus, if the growing Turkish diaspora in Europe also joins the sphere of influence.

Returning to Diyanet, it should be emphasized that this institution has an intensive impact on other ministries: the Ministry of Education, the Ministry of Health, the Ministry of Family, and the Ministry of Youth. As observed by Salim Çevik

As a result of such cooperation, the Diyanet is now active in various spheres of social life such as celebrating religious nights at university dormitories, solemnizing marriages (which was exclusively regulated by the municipalities in the past), providing educational support in elementary and high schools, providing social and psychological counselling at hospitals, marriage counselling, etc (Çevik, 2019).

In the scale of the entire Sunni world, such a powerful central structure for religious affairs is still held only by Indonesia (Bruinessen, 2018).

The eliminative direction of Turkish religious policy aimed at non-Sunnis seems to be directly proportional to the ongoing process of re-Islamization of the state, which systematically abandons the ethos of secularism once installed by Atatürk. The regime of Erdoğan restoring Sunniism in possibly all areas of public space, at the same time conducts liquidation and repressive action against opponents of such a course. Although 
Erdoğan's anti-Islamism is officially motivated by the fight against separatism and terrorism, the religious motif also seems to have its meaning, as Kurds are being increasingly accused of crypto-Yezidism, crypto-Zoroastrianism and even atheism. Furthermore, Turkish Sunniism was shaped by the so-called Hanafi School, while the Sunni Kurds obey the so-called Saffite School (Samojedny, 2013: 185-201). Of major importance is also that the Kurds in Turkey are in favour of secularization, which has ceased to be a value for Erdoğan (Pochyły, 2013: 123-126; Niekrasz, 2012: 21-39). Often, the Kurds' attitude also takes the form of non-religious nationalism (Dudra, Pochyły, 2010).

Though not as drastic as in the case of the Kurds, similar is the context of combating the Alawites committed to the doctrine of Kemalism who represent 25\% of the population (Chudziak, 2015: 153-170). The Alawites are a syncretic religious community (based on Imamism and shamanism of Turkmen), similar to Islamic Sufism. Turkish anti-Alawism with a clear Sunni background was publicized by a loud judgment of the European Court of Human Rights of April 26, 2016 in the case "İzzettin Doğan and others against Turkey” (İzzettin Doğani Inni p. Turcji, 2016; Öztürk, 2018). The proceedings concerned the violation of the right to religious freedom while discriminating against the largest religious minority in Turkey. The Court found blatant violations of the state apparatus with respect to the Alawite religious practices, which was manifested in the deprivation of their places of worship and the exclusion of their religious leaders from the principle of legal protection. This, in turn, resulted in restrictions, including those of a financial nature in the activities of their religious organization. According to the Court, the Alawite religion has clear characteristics that set it apart from privileged Sunni Islam. Ignoring this fact by Diyanet, therefore, violates the norms and standards of a democratic state and leads to the exclusion and discrimination of the entire Alawite community.

During the implementation of the liquidation anti-Kurdish policy, the Turkish state de facto made jihadists from the Islamic State their allies, and the territory of Turkey for a long time served them as a 'transport corridor' through which they reached Syria. Turkey also provided support to Sunni groups fighting the Syrian regime, including the Salafist Ahrar Ash-Sham and Jabhat al-Nusra. It was only the accumulation of accusations against Erdoğan that forced him to actively involve the Turkish army in the coalition's actions against the Islamic State (Wasilewski, 2017: 45-46). The AIVD report of the Dutch General Intelligence and Security Service, made public in November 2018, proves that they were forced and cyclical actions. It shows that the Islamic State is using Turkey's territory as a strategic base for regrouping forces and preparing new attacks in Europe (Rosman, 2018). It is hard to believe that this situation arose without Erdoğan's knowledge or even consent.

Parliamentary and presidential elections in June 2018 confirmed the success of the AKP and Erdoğan, and determined the transition of Turkey from the parliamentary system to the presidential system. With this, there occurs a break with one of the pillars 
of Kemalism, which was secularism. Simultaneous reference to nationalist and Islamic slogans is becoming the trademark of the AKP and President Erdoğan. On the other hand, the denominator of Kemalism and Erdoganism is the same status of religious minorities - in both cases encompassed by the policy of deep rationing or liquidation.

\section{Bibliography}

Adamczyk A. (2013), Trudne sąsiedztwo - wpływ relacji Turcji z sąsiadami na proces akcesji do Unii Europejskiej, "Studia Europejskie”, No. 4, pp. 72-100.

Atakuja nas najemniczki Erdogana (2018), "Euroislam", 9.05.2018, https://euroislam.pl/atakuja-nas-najemniczki-erdogana/ [access on: 4.10.2019].

Baran V. (2018), Austria zamyka meczety. Recep Tayyip Erdogan: to krok wciagajacy świat w nowa wojnę religijna, „Wirtualna Polska”, 10.06.2018, https://wiadomosci.wp.pl/austria-zamyka-meczety-recep-tayyip-erdogan-to-krok-wciagajacy-swiat-w-nowa-wojne-religijna6261183231059585a [access on: 2.10.2019].

Bekdil B. (2015), Turkey’s Dangerous Ambitions, https://www.gatestoneinstitute.org/7079/turkey-ambitions [access on: 24.12.2015].

Bruinessen van M. (2018), The Governance of Islam in Two Secular Polities: Turkey's Diyanet and Indonesia's Ministry of Religious Affairs, "European Journal of Turkish Studies”, No. 27.

Brzdąkiewicz E. (2018), Polityka zagraniczna Republiki Turcji, [in:] Wprowadzenie do polityki zagranicznej muzutmańskich państw Bliskiego Wschodu i Afryki Północnej, edit. M. Woźniak-Bobińska, A.M. Solarz, Warszawa.

Chmielowska D., Sobczak M. (2016), Demokracja po turecku, "Studia Europejskie”, No. 4, pp. 205-232.

Chudziak M. (2015), Atatürk fantazmatyzowany. Ludowe wyobrażenia o założycielu Republiki Tureckiej, "Sensus Historiae”, No. XXI(4), pp. 153-170.

Chudziak M. (2017), Pucz jako mit założycielski. Filary ideologiczne nowej Turcji, "Punkt Widzenia", No. 66.

Çevik S. (2019), Erdoğan's Comprehensive Religious Policy. Management of the Religious Realm in Turkey, "Stiftung Wissenschaft und Politik Comment", 12.03.2019, DOI: https://doi.org/10.18449/2019C12.

Dahl M. (2017), Polityka zagraniczna Turcji - uwarunkowania wewnętrzne obiektywne, "Studia Orientalistyczne", No. 1(11).

Dudra S., Pochyły P. (2010), Źródła nacjonalizmu kurdyjskiego w Turcji, "In Gremium. Studia nad Historią, Kulturą i Polityką," No. 4, pp. 111-125.

European Islamophobia Report 2015 (2016), edit. E. Bayrakl, F. Hafez, Ankara.

European Islamophobia Report 2016 (2017), edit. E. Bayrakl1, F. Hafez, Ankara.

European Islamophobia Report 2017 (2018), edit. E. Bayrakl, F. Hafez, Ankara.

Falski J. (2011), Zderzenie państwa świeckiego z państwem wyznaniowym. Turecki spór o laickość, [in:] Państwo wyznaniowe. Doktryna, prawo i praktyka, edit. J. Szymanek, Warszawa.

Gall C. (2018), Turkey Frees Pastor Andrew Brunson, Easing Tensions With U.S., "The New York Times", 12.10.2018, https://www.nytimes.com/2018/10/12/world/europe/turkey-us-pastor-andrew-brunson.html [access on: 6.10.2019].

Huntington S. (2000), Zderzenie cywilizacji i nowy kształt ładu światowego, Warszawa.

Husar-Poliszuk W., Secler B., Ślusarczyk P. (2018), Polityka wyznaniowa. Konteksty innych polityk publicznych. Austria, Katalonia, Polska, Zielona Góra.

Iddon P. (2019), Paranoja i agitacja obecne w tureckiej prasie maja znaczenie, "European Issues Institute", 4.09.2019, http://europeanissues.org/2019/09/paranoja-i-agitacja-obecne-wtureckiej-prasie-maja-znaczenie/ [access on: 4.10.2019]. 
İzzettin Doğani Inni p. Turcji, skarga nr 62649/10, streszczenie wyroku Izby z 26 kwietnia 2016 (2016), https://www.msz.gov.pl/pl/polityka_zagraniczna/europejski_trybunal_praw_czlowieka/wybrane_orzeczenia_eptcz/orzeczenia_inne_panstwa/tlumaczenia_wyrokow_europejskiego_trybunalu_praw_czlowieka_na_jezyk_polski [access on: 8.10.2019].

Jomma F. (2018), Wpływ podziałów religijnych, narodowych i etnicznych na procesy polityczne w Syrii, Szczecin.

Lewis B. (1972), Narodziny nowoczesnej Turcji, Warszawa.

Kopyś T. (2013), Polityka zagraniczna Turcji. Część II: Reakcja Turcji na przemiany społeczno-polityczne w krajach arabskich, "Polski Przegląd Stosunków Międzynarodowych", No. 3, pp. 199-219, DOI: http://dx.doi.org/10.21697/PPSM.2013.8.

Michalak R. (2019a), Polityka wyznaniowa. Zakres zjawiska, "Annales Universitatis Mariae Curie Skłodowska. Sectio K Politologia”, No. XXVI(1), pp. 23-35, DOI: http://dx.doi.or$\mathrm{g} / 10.17951 / \mathrm{k} .2019 .26 .1 .23-35$.

Michalak R. (2019b), Totalitarny islamizm czy totalny islam? Irracjonalny lęk czy uzasadniony strach? Mirosława Sadowskiego integralna i kontekstowa analiza szariatu, "Studia nad Autorytaryzmem i Totalitaryzmem: Acta Universitatis Wratislaviensis”, No. 41(3), pp. 201-213, DOI: http://dx.doi.org/10.19195/2300-7249.41.3.12.

Niekrasz J. (2012), Sytuacja Kurdów w Turcji na przestrzeni wieków, "Przegląd Narodowościowy”, No. 1.

Öztürk A.E. (2018), Transformation of the Turkish Diyanet both at Home and Abroad: Three Stages, "European Journal of Turkish Studies", No. 27.

Pochyły P. (2013), Źródła tożsamości narodowej Kurdów, "Przegląd Narodowościowy - Review of Nationalities", No. 2, pp. 113-128.

Ramme J. (2019), Framing Solidarity. Feminist Patriots Opposing the Far Right in Contemporary Poland, "Open Cultural Studies", No. 3, pp. 469-484, DOI: https://doi.org/10.1515/culture-2019-0040.

Rosman C. (2018), AIVD: IS reorganiseertzich in Turkije, "AD”, 5.11.2018, https://www.ad.nl/ binnenland/aivd-is-reorganiseert-zich-in-turkije a9feb5ae/ [access on: 10.10.2019].

Rostkowska A. (2015), Dyplomacja meczetowa i eksport islamu. Turcja chce być przywódca świata muzułmańskiego, "Gazeta Wyborcza”, 20.02.2015, http://wyborcza.pl/1,76842,17461625,_Dyplomacja_meczetowa_i_eksport_islamu_Turcja_chce.html [access on: 8.10.2019].

Sadowski M. (2017), Islam. Religia i prawo, Warszawa.

Samojedny M. (2013), Sunnickie szkoły prawa muzułmańskiego, "Acta Erasmiana”, No. 5, pp. 185-201.

Sulkowski M. (2016a), Świeckość, wolność religijna i prawa człowieka jako fundamenty demokracji liberalnej-percepcja $w$ chrześcijaństwie i islamie, [in:] Implementacja zasad religijnych $w$ sferze politycznej, edit. R. Michalak, Zielona Góra.

Sulkowski M. (2016b), Islamska rekonkwista $w$ Turcji, [in:] Religia $w$ konfliktach etnicznych we współczesnym świecie. Volume 1: Zagadnienia teoretyczne. Europa i obszar poradziecki, edit. A. Szabaciuk, D. Wybranowski, R. Zenderowski, Lublin.

Szkudlarek M. (2014), Od Atatürka do Erdoğana- ewolucja roli religii w Turcji w okresie rządów AKP, "Refleksje”, No. 9, pp. 51-69, DOI: https://doi.org/10.14746/r.2014.1.5.

Szymański A. (2008), Między islamem i kemalizmem: problem demokracji w Turcji, Warszawa.

Szymański A. (2011), Religia jako nieoficjalne kryterium członkostwa w Unii Europejskiej - przypadek Turcji, [in:] Turcja i Europa. Wyzwania i szanse, edit. A. Szymański, Warszawa.

Ślusarczyk P. (2017), Jak dr Pędziwiatr tropił “islamofobię”, "Euro Islam”, 11.04.2017, https:// euroislam.pl/jak-dr-pedziwiatr-tropil-islamofobie/ [access on: 10.10.2019].

Turan Ö. (2018), Two Modalities of Foreign and Domestic Policies in Turkey: From Soft Power to War Rhetoric, "Journal of Conflict Transformation: Caucasus Edition", No. 3(2). 
Urbanik A. (2014), Neoosmanizm: polityka zagraniczna Turcji okresu rzadów Partii Sprawiedliwości $i$ Rozwoju (AKP), "Edukacja Humanistyczna”, No. 2(31), pp. 29-44.

Wasilewski K. (2017), Raport. Turcja w procesie przemian: wnioski dla strategii UE, Warszawa. Wódka J. (2012), Nowy wymiar tureckich aspiracji mocarstwowych. Soft power Turcji, [in:] Bezpieczeństwo narodowe i międzynarodowe w regionie Bliskiego Wschodu i Północnej Afryki (MENA) u progu XXI wieku, edit. R. Bania, K. Zdulski, Łódź.

Wódka J. (2013), Polityka zagraniczna "nowej” Turcji. Implikacje dla partnerstwa transatlantyckiego, "System euroatlantycki w wielobiegunowym świecie i jego perspektywy", No. 3, Warszawa.

Wójcik J. (2018), Turcja, czyli zanim zaczniesz grać w wielka politykę, zawiąż buty, "Układ Sił”, No. 10.

Wójcik J. (2019), Diyanet - religia w służbie polityki, polityka w służbie religii, "European Issues Institute", 10.02.2019, http://europeanissues.org/2019/02/diyanet-religia-w-sluzbie-politykipolityka-w-sluzbie-religii/ [access on: 2.10.2019].

Zasuń A. (2018), Polityczny islam. Między religią polityczną a instrumentalizacją religii w polityce, Częstochowa.

Zenderowski R., Michalak R. (2018), Polityka wyznaniowa. Aspekty teoretyczne i egzemplifikacje, Zielona Góra.

Zieliński T.J. (2011), Państwo wyznaniowe - analiza typologiczna, [in:] Państwo wyznaniowe. Doktryna, prawo i praktyka, edit. J. Szymanek, Warszawa.

Abstract: The author of the article undertakes an attempt to establish the reasons and manifestations of the increased importance of the religious factor in the policy of contemporary Turkey, as well as to capture the transformations taking place in Turkish religious policy. The author believes that the last-mentioned process strictly corresponds to the phenomena of withdrawal from the model of nonreligious autocracy which was one of the main characteristics of Kemalism in favour of the model of a country which is de facto religious. This, in turn, becomes the emblem of Neoosmanism. The parliamentary and presidential elections of June 2018 confirmed the success of the AKP and Erdoğan, and determined the transition of Turkey from the parliamentary system to the presidential system. At that time, there is a propaganda offensive combining nationalist and Islamic slogans. The tangible proof of Turkey's re-Islamization is the radical increase in the importance of Diyanet - the ministry of religious affairs. This institution also serves foreign policy, often referred to as mosque policy, due to the fact that its focus is put on marking the greatness of the Islamic Turkey around the world. In the research procedure, a method of critical analysis of the content of studies and the available sources were used. Keywords: Turkey, Turkish Confessional Policy, domestic policy, foreign policy, Islamic nationalism, state and religion, political Islam, Middle East, Diyanet, Kemalism, Erdoganism, Sunniism, religious minority

Article submitted: 10.10.2019; article accepted: 30.10.2019. 